\title{
Preparation of Ordered Sulfonated Mesoporous Polymer (OMP-TsOH) from $p$-Toluenesulfonic Acid and Application in Esterification Reaction of Fatty Acids
}

\author{
Arash Shokrolahi,* Abbas Zali, Hamid Reza Pouretedal and Ali Mousaviazar \\ Chemistry Department, Malek-ashtar University of Technology, Shahin-shahr, P.O. Box 83145-115, I. R. Iran
}

\begin{abstract}
Polímero sulfonado mesoporoso ordenado foi preparado pela comistura de $p$-formaldeído, ácido $p$-toluenosulfônico ( $p$-TsOH) e ácido sulfúrico. Sílicas mesoporosas SBA-15 e/ou MCM48 foram utilizadas como moldes. Elevadas área superficial específica e densidade ácida dos novos ácidos sólidos foram obtidas no intervalo 900-1400 $\mathrm{m}^{2} \mathrm{~g}^{-1} \mathrm{e} \mathrm{4,9} \mathrm{mmol} \mathrm{g}^{-1}$, respectivamente. Catalisadores preparados com o molde SBA-15 apresentaram maiores diâmetros de poros, e o uso do molde MCM-48 é devido a maior área superficial específica. As atividades catalíticas dos sólidos ácidos foram estudadas na reação de esterificação do ácido oleico. As taxas iniciais dos ácidos sólidos com os moldes SBA-15 e MCM-48 foram 80-93 e 62-80 $\mu$ mol min ${ }^{-1}$, respectivamente. Catalisador com maior diâmetro de poro apresentou maior taxa inicial da reação de esterificação e maior eficiência de conversão do ácido oleico. Consequentemente, o diâmetro de poro exerceu um papel crucial na atividade catalítica.
\end{abstract}

Sulfonated ordered mesoporous polymer was simply prepared by co-mixing $p$-formaldehyde, $p$-toluenesulfonic acid ( $p$-TsOH) and sulfuric acid. SBA-15 and/or MCM-48 mesoporous silicas were used as templates. High specific surface area and acid density of the novel solid acids were obtained in the range $900-1400 \mathrm{~m}^{2} \mathrm{~g}^{-1}$ and of $4.9 \mathrm{mmol} \mathrm{g}^{-1}$, respectively. Catalysts prepared with SBA-15 template presented higher pore diameter, and the use of the MCM-48 template is due to higher specific surface area. The catalytic activities of the solid acids were studied in oleic acid esterification reaction. The initial rates of the solid acids with templates of SBA-15 and MCM-48 were $80-93$ and $62-80 \mu \mathrm{mol} \mathrm{min}^{-1}$, respectively. Catalyst with higher pore diameter showed the higher initial rate of esterification reaction and higher conversion efficiency of oleic acid. Consequently, the pore diameter played a crucial role in catalytic activity.

Keywords: mesoporous polymer, esterification, $p$-toluenesulfonic acid, SBA-15, MCM-48, solid acid

\section{Introduction}

Acids are widely used as catalyst in process of production of more than $1 \times 10^{8} \mathrm{mt}$ per year of chemical materials. The mineral acids such as $\mathrm{HF}, \mathrm{H}_{2} \mathrm{SO}_{4}, \mathrm{HClO}_{4}$ and $\mathrm{HCl}$ are commonly used in the most of process. Although these acids are inexpensive and highly active, their use is wasteful and energy-inefficient, requiring separation, recycling and treatment of waste acid. The solid acids as substituent show many advantages such as simplicity in handling, decrease of reactor and plant, decrease of corrosion effects and environmentally safe disposal. ${ }^{1-4}$

Although solid acid catalysts present very important roles, there are still drawbacks. For instance, the

*e-mail: ar_shokrolahi@mut-es.ac.ir, arshokrolahi@gmail.com specific surface areas of oxides and resins are quite low $\left(<100 \mathrm{~m}^{2} \mathrm{~g}^{-1}\right)$. The specific surface area of zeolites are larger $\left(>400 \mathrm{~m}^{2} \mathrm{~g}^{-1}\right)$ compared with oxides and resins, but the facts that micropores in zeolites are relatively small and the major type strongly influence on the mass transfer and conversion of bulky molecules in catalysis. ${ }^{5-7}$

Porous materials and their products are attractive because of huge scientific applications in industry. They are used as supports for different catalytic processes, fuel cells, separation, purification and capacitors. Porous polymere with high specific surface areas and well developed porosities are widely used during the years because they can fulfill most of the desirable properties as suitable catalyst supports. The porous solid-acid catalysts can be synthesized in two steps. At first step, the porous materials are prepared and then are sulfonated at harsh oxidation 


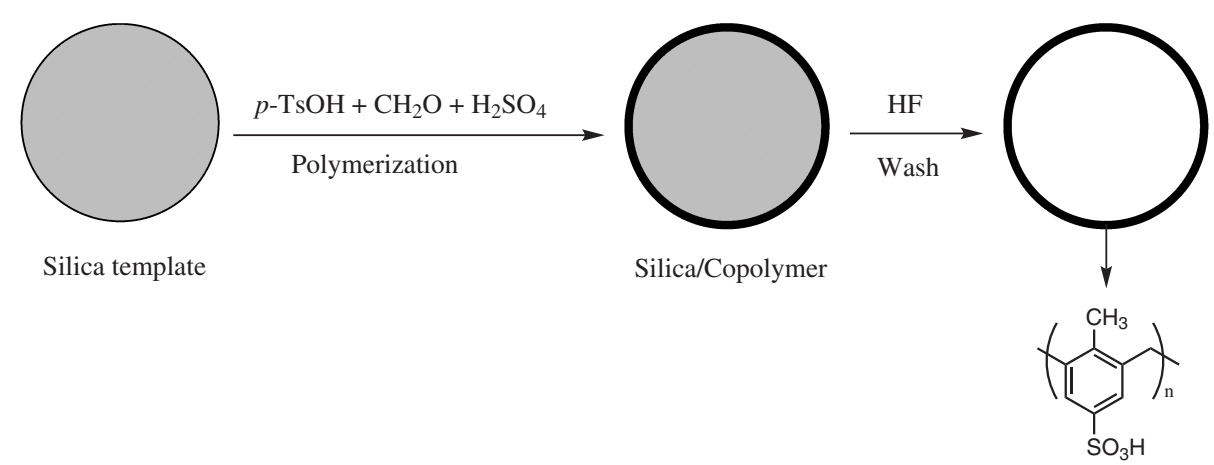

Scheme 1.

conditions or prepared by covalent attachment of sulfonic acid-containing aryl radical in a second step. ${ }^{8-29}$

The porous silicas or zeolites are used for the synthesis of ordered meso- and microporous materials. ${ }^{30-38}$ The infiltration of the inorganic template with an appropriate carbon source, the carbonization of precursor and the subsequent removal of inorganic template with HF solutions are used to prepare ordered meso- and microporous carbons.

Herein, it is reported a facile and low-danger method to synthesize sulfonic acid-functionalized ordered mesoporous polymer catalysts by co-mixing $p$-formaldehyde, $p$-toluenesulfonic acid ( $p$-Ts $\mathrm{SH})$ and mesoporous silica SBA-15 and/or MCM-48 as a template in a sealed vessel under thermal treatment at $120{ }^{\circ} \mathrm{C}$ (Scheme 1). The resulting material was examined as solid acid catalyst in the oleic acid esterification with methanol, and its catalytic performance was compared with other commercial acidic catalysts. The effects of specific surface area and pore size on the catalytic reactivity and the successful reuse of catalysts are demonstrated in this report.

\section{Experimental}

\section{General experimental information}

Chemical reactants were purchased from Fluka, Merck and Aldrich. Two types of mesoporous silica (MCM48 and SBA-15) were synthesized according to procedures already described in the literature. ${ }^{39-42}$ Fourier transform infrared spectra (FTIR) were recorded on a Nicolet Impact 400D spectrophotometer. Thermogravimetric analyses (TG) were carried out in a Metter TG 50. X-ray diffraction patterns (XRD) were obtained on a Bruker D8 ADVANCE instrument. Scanning electron microscopy (SEM) images were taken on a Philips XL30 and Seron Technology AIS-2100 instruments. Specific surface area and mean pore diameter $(\mathrm{dp})$ were calculated from adsorption isotherms of nitrogen at $77 \mathrm{~K}$ using the standard Brunauer-
Emmett-Teller (BET) equation using a NOVA 2200 MultiStation High Speed Gas Sorption Analyzer version 7.11, Quantachrome Corporation. Elemental analysis was obtained on a Vario EL III instrument.

\section{Synthesis of the catalysts}

In a typical synthesis, $0.8 \mathrm{~g}$ of $p$-TsOH, $0.36 \mathrm{~g}$ $p$-formaldehyde and $0.8 \mathrm{ml}$ sulfuric acid were added to dehydrated mesoporous silica (SBA-15 or MCM-48) in a $30 \mathrm{~mL}$ Teflon-sealed vessel, stirred at $80^{\circ} \mathrm{C}$ for $24 \mathrm{~h}$ and then maintained at $120^{\circ} \mathrm{C}$ for $24 \mathrm{~h}$. The product was washed with boiling distilled water until impurities such as sulfate ions were no longer detected in the wash water. To obtain the polymeric material from the silica/copolymer composite, the silica was removed using aqueous $\mathrm{HF}$ solution. $30 \mathrm{~mL}$ of $10 \%$ aqueous HF solution were added to $1.0 \mathrm{~g}$ of the silica/ copolymer composite in a Teflon beaker, and the mixture was allowed to stand for $24 \mathrm{~h}$ at room temperature. The supernatant solution containing silica was removed, and the black precipitate was repeatedly washed with distilled water until $\mathrm{F}^{-}$was no longer detected in the wash water to get a pure material of ordered sulfonated mesoporous polymer. The ordered sulfonated mesoporous polymer samples were designated as OMP-TsOH- $x$, where $x$ indicates the batch number (Table 1). The structural properties of the samples are summarized in Tables 2 and 3.

Table 1. Copolymer/silica composite conditions

\begin{tabular}{lcc}
\hline Sample & $\begin{array}{c}\text { Weight ratio of copolymer to } \\
\text { mesoporous silica / } \%(\mathrm{~m} / \mathrm{m})\end{array}$ & Support \\
\hline OMP-TsOH-1 & 14.9 & SBA-15 \\
OMP-TsOH-2 & 20.3 & SBA-15 \\
OMP-TsOH-3 & 30.1 & SBA-15 \\
OMP-TsOH-4 & 41.0 & SBA-15 \\
OMP-TsOH-5 & 15.1 & MCM-48 \\
OMP-TsOH-6 & 20.1 & MCM-48 \\
OMP-TsOH-7 & 31.0 & MCM-48 \\
OMP-TsOH-8 & 41.2 & MCM-48 \\
\hline
\end{tabular}


Table 2. Structural characteristics of the ordered sulfonated mesoporous polymer obtained by silica removal from copolymer/SBA-15 composites

\begin{tabular}{lccc}
\hline Sample & $\begin{array}{c}\text { Specific surface } \\
\text { area } /\left(\mathrm{m}^{2} \mathrm{~g}^{-1}\right)\end{array}$ & $\begin{array}{c}\text { Pore-volume / } \\
\left(\mathrm{cm}^{3} \mathrm{~g}^{-1}\right)\end{array}$ & $\begin{array}{c}\text { Pore diameter / } \\
\mathrm{nm}\end{array}$ \\
\hline SBA-15 & 935 & 1.2 & 8.3 \\
OMP-TsOH-1 & 920 & 0.8 & 8.1 \\
OMP-TsOH-2 & 910 & 0.7 & 8.1 \\
OMP-TsOH-3 & 900 & 0.7 & 7.2 \\
OMP-TsOH-4 & 805 & 0.6 & 6.9 \\
\hline
\end{tabular}

Table 3. Structural characteristics of the ordered sulfonated mesoporous polymer obtained by silica removal from copolymer/MCM-48 composite

\begin{tabular}{lccc}
\hline Sample & $\begin{array}{c}\text { Specific surface } \\
\text { area / }\left(\mathrm{m}^{2} \mathrm{~g}^{-1}\right)\end{array}$ & $\begin{array}{c}\text { Pore volume / } \\
\left(\mathrm{cm}^{3} \mathrm{~g}^{-1}\right)\end{array}$ & $\begin{array}{c}\text { Pore diameter / } \\
\mathrm{nm}\end{array}$ \\
\hline MCM-48 & 1465 & 1.0 & 2.6 \\
OMP-TsOH-5 & 1437 & 0.6 & 1.9 \\
OMP-TsOH-6 & 1117 & 0.5 & 2.5 \\
OMP-TsOH-7 & 1075 & 0.3 & 2.2 \\
OMP-TsOH-8 & 1001 & 0.3 & 1.9 \\
\hline
\end{tabular}

\section{Acid-catalyzed reaction}

Catalytic esterification of oleic acid $\left(\mathrm{C}_{17} \mathrm{H}_{33} \mathrm{COOH}\right.$, $0.025 \mathrm{~mol})$ with methanol $(0.25 \mathrm{~mol})$ was performed under $\mathrm{N}_{2}$ atmosphere at $80{ }^{\circ} \mathrm{C}$. Prior to reaction, tested catalysts except sulfuric acid evacuated at $100{ }^{\circ} \mathrm{C}$ for $1 \mathrm{~h}$ to remove adsorbed water. The amount of acid catalyst in reaction was always $1 \mathrm{mmol} \mathrm{H} \mathrm{H}^{+}$. The liquid phase was analyzed by a gas chromatograph-mass spectrometer (Agilent, 5975C) during reaction.

The reactions were carried out in a $50 \mathrm{~mL}$ three-neck round bottom glass flask with a reflux condenser to minimize methanol losses. The flask submerged in an oil bath was placed on a temperature-controlled magnetic stirring hotplate. The reaction temperature was monitored by thermocouple as well as mercury thermometer, and held within $\pm 1{ }^{\circ} \mathrm{C}$.

\section{Results and Discussion}

The density of prepared acid (OMP-TsOH- $x$ ) was determined using $0.01 \mathrm{~mol} \mathrm{~L}^{-1} \mathrm{NaOH}$ as titrant in an acid-base potentiometric titration and the result obtained was $4.9 \mathrm{mmol} \mathrm{g}^{-1}$. The $\mathrm{X}$-ray diffraction data for OMP-TsOH-3 and OMP-TsOH-7 exhibited two broad and weak peaks at $2 \theta / 10-30^{\circ}$ and $35-45^{\circ}$ that were attributed to the amorphous structure (Figures $1 \mathrm{a}$ and $1 \mathrm{~b}$ ).

Figure 2 shows the SEM images of SBA-15, OMP-TsOH-3, MCM-48, OMP-TsOH-7. There is no
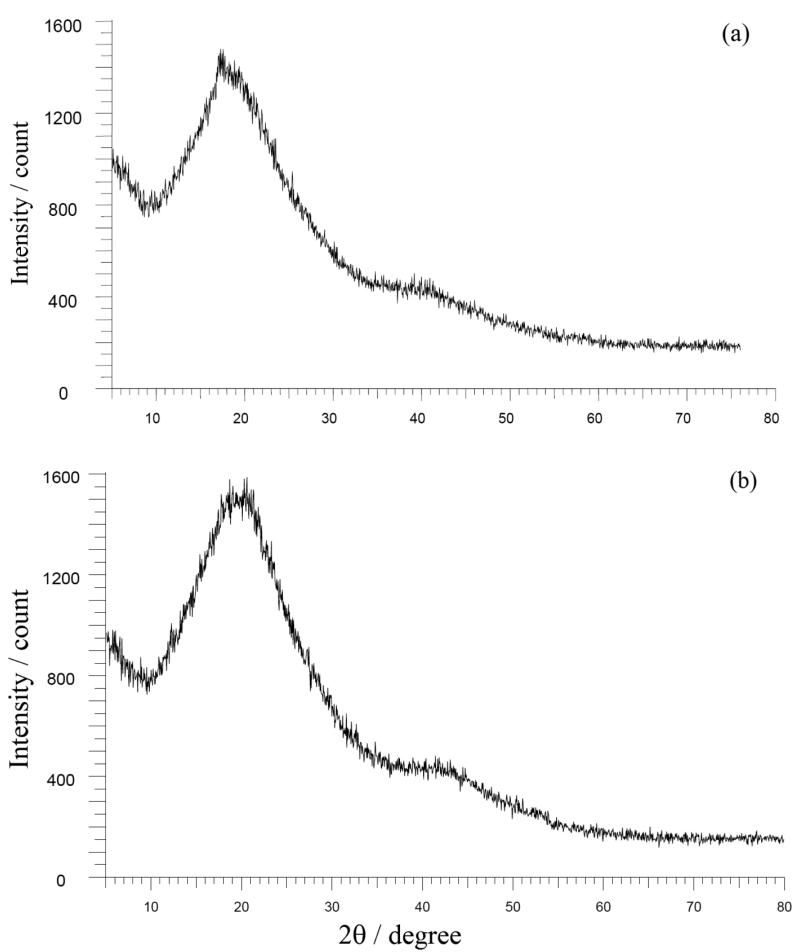

Figure 1. XRD patterns of (a) of OMP-TsOH-3 and (b) OMP-TsOH-7.

significant difference between the surface morphology of mesoporous silica (SBA-15 or MCM-48) and OMP-TsOH-3 and/or OMP-TsOH-7.

The IR spectra of OMP-TsOH-3 and $p-\mathrm{TsOH}$ are compared in Figures $3 \mathrm{a}$ and $3 \mathrm{~b}$. The results show that the differences between them are not obvious.

Figure 4 shows the nitrogen adsorption-desorption isotherms of SBA-15, MCM-48, OMP-TsOH-3 and OMP-TsOH-7. The isotherms of OMP-TsOH-3 and OMP-TsOH-7 are of type IV according to the IUPAC classification and exhibit a $\mathrm{H} 1$ hysteresis loop.

The thermal stabilities of OMP-TsOH-3 and OMP-TsOH-7 were examined by thermogravimetric analysis (Figure 5). After an initial weight loss due to evaporation of absorbed water, the decomposition reaction started at around $200^{\circ} \mathrm{C}$. An approximate similar decomposition process was observed for all other samples.

\section{Evaluation of OMP-TsOH-x}

The catalytic performance of OMP-TsOH- $x$ was demonstrated through the oleic acid esterification with methanol. The efficiency of oleic acid esterification was measured at $80{ }^{\circ} \mathrm{C}$ over OMP-TsOH- $x$, protonated Nafion (NR50), copolymer $p$-TsOH ${ }^{43}$ and concentrated sulfuric acid. In the absence of acid catalyst, the conversion of oleic acid was only $5.15 \%$ in $10 \mathrm{~h}$. The specific surface areas, acid densities, added amount of catalyst 
(a)

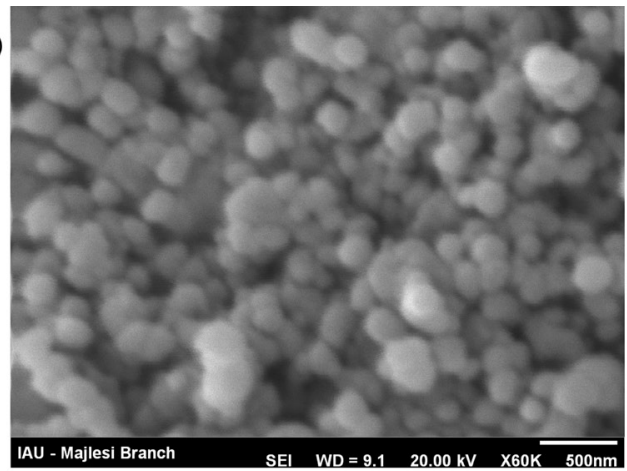

(c)

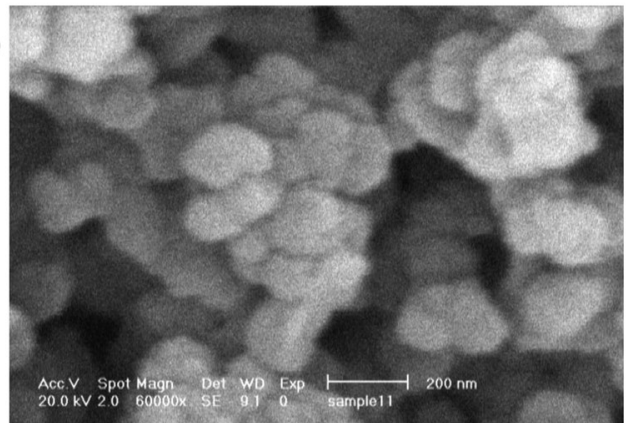

(b)

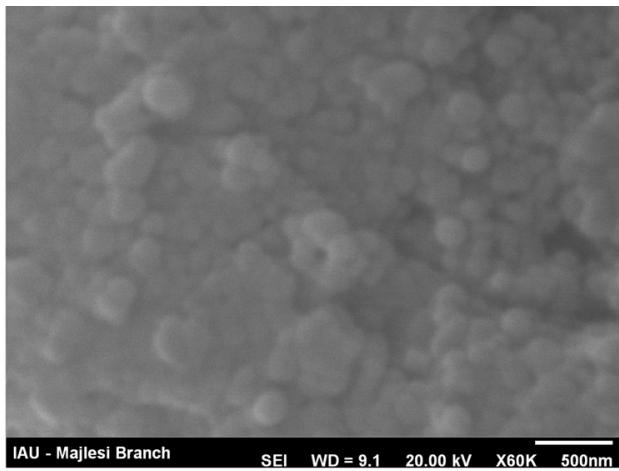

(d)

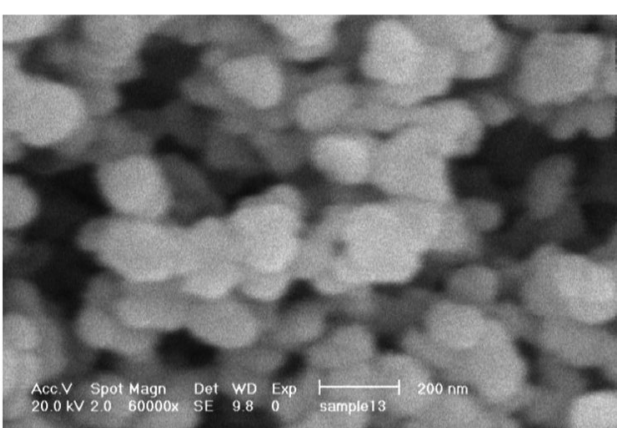

Figure 2. SEM images of (a) SBA15, (b) OMP-TsOH-3, (c) MCM-48 and (d) OMP-TsOH-7.

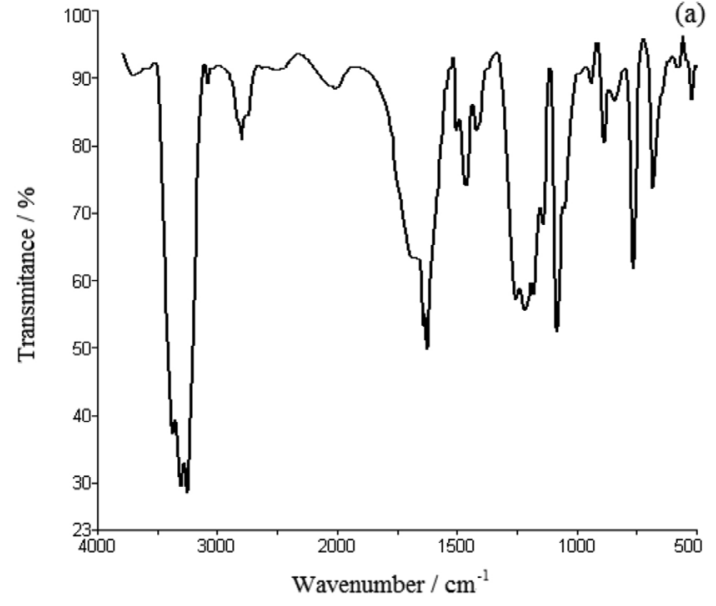

Figure 3. The IR spectra of (a) OMP-TsOH-3 and (b) $p$ - TsOH.

$\left(\mathrm{H}^{+}=1 \mathrm{mmol}\right)$, initial rate of methyl oleate formation are summarized in Table 4.

It is evident from Table 4 that the $\mathrm{H}_{2} \mathrm{SO}_{4}$ homogeneous catalyst shows the highest activity with a conversion of more than $60 \%$ in less than 120 min and initial rate of $164.8 \mu \mathrm{mol} \mathrm{min}^{-1}$. Among heterogeneous catalysts, the prepared sulfonated mesoporous polymer (OMP-TsOH- $x$ ) with initial rate of $62.75-93.4 \mu \mathrm{mol} \mathrm{min}^{-1}$ presented a higher catalytic activity in methyl oleate formation reaction. The higher catalytic activity of OMP-TsOH- $x$ is due to the high specific surface area, high acid site density, high density of pores (which provide good access to the $\mathrm{SO}_{3} \mathrm{H}$ groups on the surface) and hydrophobicity.

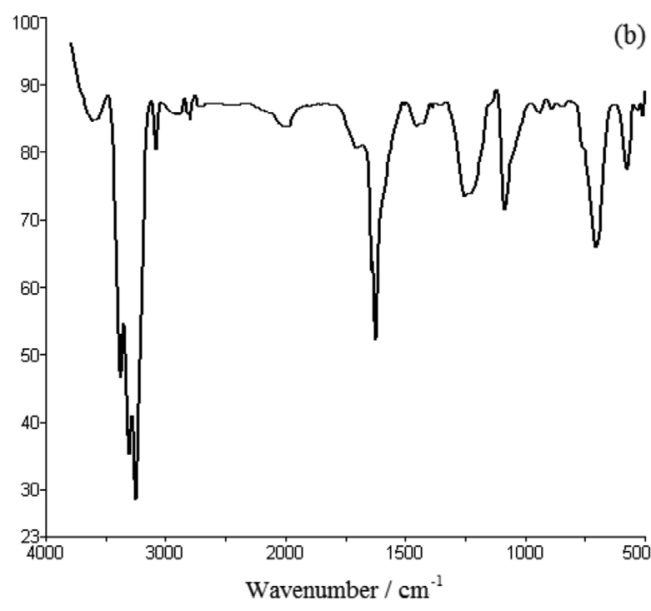

OMP-TsOH- $x(x=1-4)$ with mean initial rate value of $87.8 \mu \mathrm{mol} \mathrm{min}{ }^{-1}$ of the esterification reaction presented the higher activity in comparison with OMP-TsOH- $x$

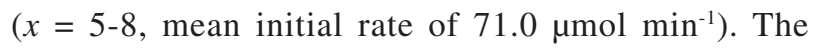
calculated average pore diameters of OMP-TsOH- $x$ with $x=1-4$ and OMP-TsOH- $x$ with $x=5-8$ were 7.6 and $2.1 \mathrm{~nm}$, respectively.

The pore diameter increase of the OMP-TsOH- $x$ catalyst was accompanied by an increase of $23 \%$ in the average initial rate of the esterification. Therefore, the pore diameter of the templates (SBA-15 and MCM-48) plays a serious role in catalytic activity. Moreover, apparently, the high specific surface area of MCM-48 was not a 

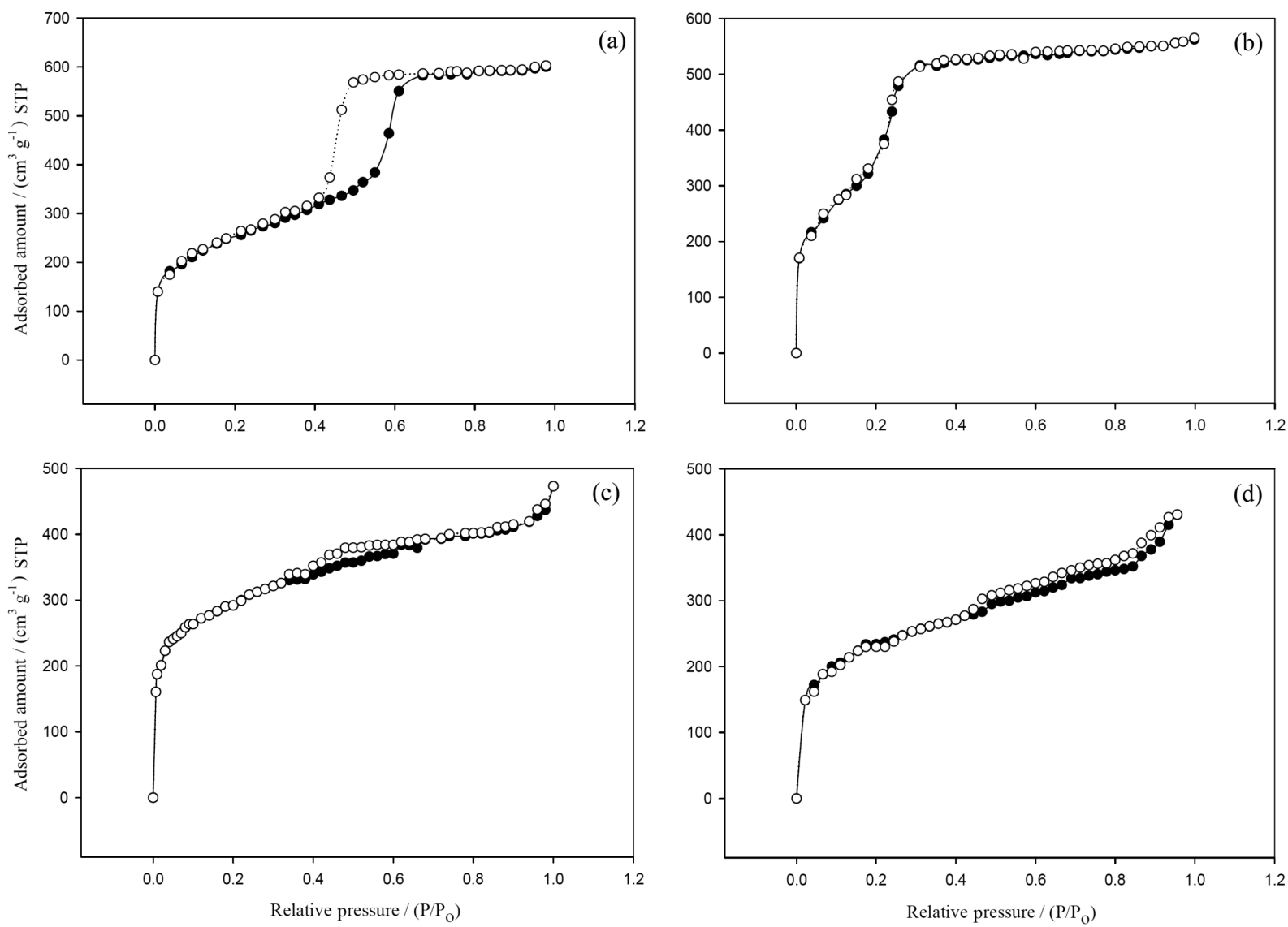

Figure 4. The nitrogen adsorption-desorption isotherms of (a) SBA-15, (b) MCM-48, (c) OMP-TsOH-3 and (d) OMP-TsOH-7.

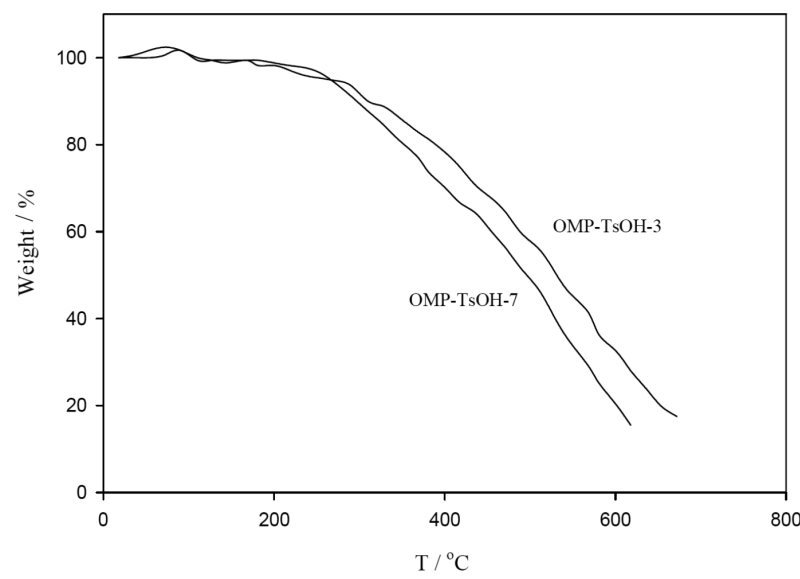

Figure 5. Thermogravimetric curves of OMP-TsOH-3 and OMP-TsOH-7.

fundamental characteristic in the oleic acid conversion rate. The increase of catalytic activity is due to the large pore size, aiding the swift diffusion of large organic molecules to the active sites. ${ }^{5-7}$

These results are confirmed by comparing the data of OMP-TsOH- $x(x=5-8)$ (Tables 3 and 4). OMP-TsOH-6 with the highest pore diameter $(2.5 \mathrm{~nm})$ presented the

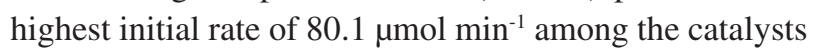
with MCM-48 template. The calculated pore diameter of OMP-TsOH-5 and OMP-TsOH-8 was $1.9 \mathrm{~nm}$, but OMP-TsOH-5 with higher specific surface area showed higher initial rate $\left(70.1\right.$ vs. $\left.62.8 \mu \mathrm{mol} \mathrm{min}{ }^{-1}\right)$. Thus, the specific surface area of the template plays as second role in the determining of the initial rate and conversion yield.

However, in the case of OMP-TsOH- $x(x=1-4)$ catalysts, the initial rate and conversion yield decreased with the reduction of the specific surface area and pore diameter. The obtained results are summarized in Figures 6 and 7. As observed, OMP-TsOH- $x(x=1-4)$ catalysts with the higher pore diameter but lower specific surface areas showed higher initial rate in comparison with OMP-TsOH- $x(x=5-8)$ catalysts. With equal pore diameter, a higher specific surface area produced a higher initial rate.

To check the reusability and recyclability of the catalyst (OMP-TsOH-1), it was carried out the oleic acid esterification under similar reaction conditions. The catalyst was separated by filtration after completion of the reaction. It was also dried and used for subsequent experiments after adding fresh substrate under similar reaction conditions. For three catalytic cycles, the initial rate values of methyl oleate formation were $92.8,90.6$ and $92.0 \mu \mathrm{mol} \mathrm{min}{ }^{-1}$. However, the reaction time gradually increased with the 
Table 4. The specific surface areas, acid densities, added amount of catalyst, initial rate of methyl oleate formation catalyzed by different acids ${ }^{\mathrm{a}}$

\begin{tabular}{lccccc}
\hline Acid & $\begin{array}{c}\text { Acid density / } \\
\left(\mathrm{mmol} \mathrm{g}^{-1}\right)\end{array}$ & $\begin{array}{c}\text { Specific surface area / } \\
\left(\mathrm{m}^{2} \mathrm{~g}^{-1}\right)\end{array}$ & $\begin{array}{c}\text { Added amount / } \\
\mathrm{g}\end{array}$ & $\begin{array}{c}\text { Initial rate / } \\
\left(\mu \mathrm{mol} \mathrm{min}^{-1}\right)\end{array}$ & $\begin{array}{c}\text { Conversion / \% } \\
(\mathrm{time})\end{array}$ \\
\hline $\mathrm{H}_{2} \mathrm{SO}_{4}$ & 20.4 & - & 0.05 & 164.8 & $63.7(120 \mathrm{~min})$ \\
Nafion (NR50) & 0.9 & $<0.1$ & 1.1 & 36.4 & $49.0(10 \mathrm{~h})$ \\
Copolymer- -TsOH & 5.0 & 15 & 0.2 & 41.6 & $50.1(10 \mathrm{~h})$ \\
OMP-TsOH-1 & $4.9(4.95)^{\mathrm{b}}$ & 920 & 0.2 & 03.4 & $62.4(6 \mathrm{~h})$ \\
OMP-TsOH-2 & 4.9 & 910 & 0.2 & 93.3 & $62.1(6 \mathrm{~h})$ \\
OMP-TsOH-3 & 5.0 & 900 & 0.2 & 83.8 & $59.5(6 \mathrm{~h})$ \\
OMP-TsOH-4 & 4.9 & 1437 & 0.2 & 70.1 & $58.9(6 \mathrm{~h})$ \\
OMP-TsOH-5 & 4.9 & 1117 & 0.2 & 80.1 & $59.4(6 \mathrm{~h})$ \\
OMP-TsOH-6 & 4.9 & 1075 & 0.2 & 71.1 & $61.0(6 \mathrm{~h})$ \\
OMP-TsOH-7 & 4.9 & 1001 & 0.2 & 62.8 & $58.9(6 \mathrm{~h})$ \\
OMP-TsOH-8 & 4.9 & & $56.0(6 \mathrm{~h})$ & 5 \\
\hline
\end{tabular}

${ }^{a}$ Reaction condition: acid-catalyzed $\left(\mathrm{H}^{+}=1 \mathrm{mmol}\right)$ oleic acid esterification $(25 \mathrm{mmol})$ with methanol $(250 \mathrm{mmol})$ at $353 \mathrm{~K}$; be density of $\mathrm{SO}_{3} \mathrm{H}$ group of OMP-TsOH-1 was determined on the base of elemental analysis $\left(\mathrm{CH}_{1.13} \mathrm{O}_{0.34} \mathrm{~S}_{0.11}\right)$.

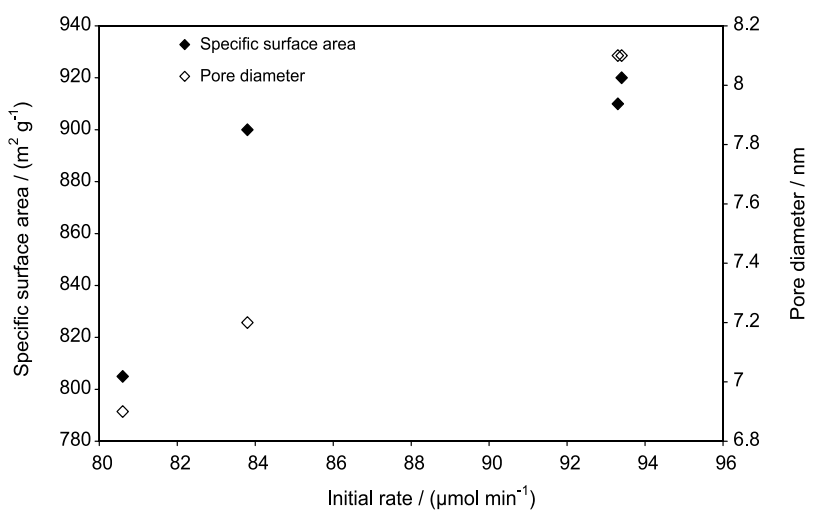

Figure 6. The dependence of the initial rate to the specific surface area and pore diameter of SBA-15 support.

comparable yields of the methyl oleate in subsequent recycle experiments.

\section{Conclusions}

A simple procedure was introduced to prepare of sulfonic acid-functionalized ordered mesoporous polymer catalysts. The specific surface area and pore diameter parameters of the mesoporous polymer catalysts determined the catalytic activity. The pore diameter of the templates showed more importance in the determination of catalytic activity. Moreover, the pore size also showed to be an important parameter for a porous material in a catalytic application to esterification of fatty acids because this process involves large organic molecules.

\section{Supplementary Information}

Supplementary data are available free of charge at http://jbcs.sbq.org.br as PDF file.

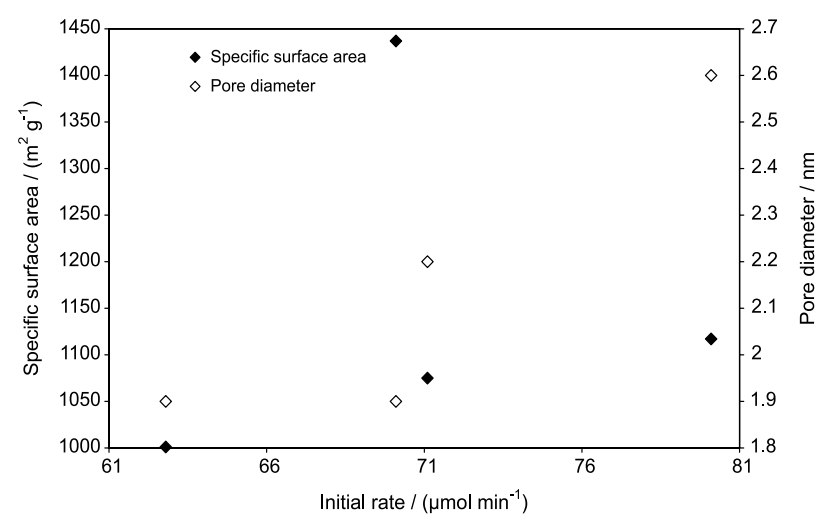

Figure 7. The dependence of initial rate to specific surface area and pore diameter of MCM-48 support.

\section{References}

1. Corma, A.; Chem. Rev. 1995, 95, 559.

2. Corma, A.; Curr. Opin. Solid State Mater. Sci. 1997, 2, 63.

3. Corma, A.; Garcia, H.; Catal. Today 1997, 38, 257.

4. Okuhara, T.; Chem. Rev. 2002, 102, 3641.

5. Corma, A.; Chem. Rev. 1997, 97, 2373.

6. Tao, Y.; Kanoh, H.; Abrams, L.; Kaneko, K.; Chem. Rev. 2006, 106, 896.

7. Davis, M. E.; Nature 2002, 417, 813.

8. Johnson, S. A.; Ollivier, P. J.; Mallouk, T. E.; Science 1999, 283, 963.

9. Wainer, M.; Marcoux, L.; Kleitz, F.; J. Mater. Sci. 2009, 44, 6538.

10. Liu, Y.; J. Porous Mater. 2011, 18, 597.

11. Kim, J. Y.; Yoon, S. B.; Koolib, F.;Yu, J.-S.; J. Mater. Chem. 2001, 11, 2912.

12. Jang, J.; Bae, J.; Chem. Commun. 2005, 1200.

13. Wu, F. C.; Tseng, R. L.; J. Colloid. Interf. Sci. 2006, 294, 21. 
14. Marsh, H.; Rodriguez-Reinoso, F.; Activated Carbon; Elsevier Science \& Technology Books, 2006.

15. Sun, R. Q.; Sun, L. B.; Chun, Y.; Xu, Q. H.; Carbon 2008, 46, 1757.

16. Miller, T. C.; Holcombe, J. A.; Anal. Chim. Acta 2002, 455, 233.

17. Thomas, K. M.; Catal. Today 2007, 120, 389.

18. Nakagawa, Y.; Molina-Sabio, M.; Rodriguez-Reinoso, F.; Microp. Mesop. Mater. 2007, 103, 29.

19. Caiazzo, A.; Dalili, S.; Picard, C.; Sasaki, M.; Siu, T.; Yudin, A. K.; Pure Appl. Chem. 2004, 76, 603.

20. Blanco, J.; Petre, A. L.; Yates, M.; Martin, M. P.; Suarez, S.; Martin, J. A.; Adv. Mater. 2006, 18, 1162.

21. Xu, C.; Liu, Y.; Yuan, D.; Int. J. Electrochem. Sci. 2007, 2, 674.

22. Kudo, S.; Maki, T.; Miura, K.; Mae, K.; Carbon 2010, 48, 1186.

23. Shen, W.; Li, Z.; Liu, Y.; Recent Pat. Chem. Eng. 2008, 1, 27.

24. Machnikowski, J.; Grzyb, B.; Machnikowska, H.; Weber, J. V.; Microp. Mesop. Mater. 2005, 82, 113.

25. Olivares-Marín, M.; Fernández-González, G. C.; Macías-García A.; Gómez-Serrano, V.; Appl. Surf. Sci. 2006, 252, 5967.

26. Kitano, M.; Arai, K.; Kodama, A.; Kousaka, T.; Nakajima, K.; Hayashi, S.; Hara, M.; Catal. Lett. 2009, 131, 242.

27. Lee, J. B.; Park, Y. K.; Yang, O.; Kanga, Y.; Jun, K.; Lee, Y. J.; Kima, H. Y.; Lee K. H.; Choi, W. C.; J. Power Sources 2006, 158,1251 .

28. Shu, Q.; Gao, J.; Nawaz, Z.; Liao, Y.; Wang, D.; Wang, J.; Appl. Energy 2010, 87, 2589.

29. Mirza-Aghayan, M.; Boukherroub, R.; Bolourtchian, M.; Hosseini, M.; Tetrahedron Lett. 2003, 44, 4579.
30. Lee, J. S.; Joo, S. H.; Ryoo, R.; J. Am. Chem. Soc. 2002, 124, 1156.

31. Jun, S.; Joo, S. H.; Ryoo, R.; Kruk, M.; Jaroniec, M.; Liu, Z.; Ohsuna, T.; Terasaki, O.; J. Am. Chem. Soc. 2000, 122, 10712.

32. Kiotani, T.; Nagai, T.; Inoue, S.; Tomita, A.; Chem. Mater. 1997, 9, 609 .

33. Barata-Rodrigues, P. M.; Mays, T. J.; Moggridge, G. D.; Carbon 2003, 41, 2231.

34. Darmstadt, H.; Roy, C.; Kaliaguine, S.; Choi, S. J.; Ryoo, R.; Carbon 2002, 40, 2673.

35. Joo, S. H.; Jun, S.; Ryoo, R.; Microp. Mesop. Mater. 2001, 44-45, 153.

36. Kim, J.; Lee J.; Hyeon, T.; Carbon 2004, 42, 2711.

37. Fuertes, A. B.; Alvarez, S.; Carbon 2004, 42, 3049.

38. Fuertes, A. B.; Nevskaia, D. M.; Microp. Mesop. Mater. 2003, 62, 177.

39. Bandyopadhyay, M.; Gies, H. C. R.; Chimie 2005, 8, 621.

40. Gies, H.; Grabowski, S.; Bandyopadhyay, M.; Tkachenko, O. P.; Klementiev, K.; Grünert, W.; Birkner, A.; Microp. Mesop. Mater. 2003, 60, 31.

41. Zhao, D.; Feng, J.; Huo, Q.; Melosh, N.; Fredrickson, H. G.; Chmelka, B. F.; Stucky, G. D.; Science 1998, 279, 548.

42. Zhao, D.; Huo, Q.; Freng, J.; Chmelka, B. F.; Stucky, G. D.; J. Am. Chem. Soc. 1998, 120, 6024.

43. Liang, X.; Gao, S.; Gong, G.; Wang, Y.; Yang, J. G.; Catal. Lett. 2008, 124, 352.

Submitted: March 14, 2012

Published online: June 6, 2012 


\title{
Preparation of Ordered Sulfonated Mesoporous Polymer (OMP-TsOH) from $p$-Toluenesulfonic Acid and Application in Esterification Reaction of Fatty Acids
}

\author{
Arash Shokrolahi,*Abbas Zali, Hamid Reza Pouretedal and Ali Mousaviazar
}

Chemistry Department, Malek-ashtar University of Technology, Shahin-shahr, P.O. Box 83145-115, I. R. Iran
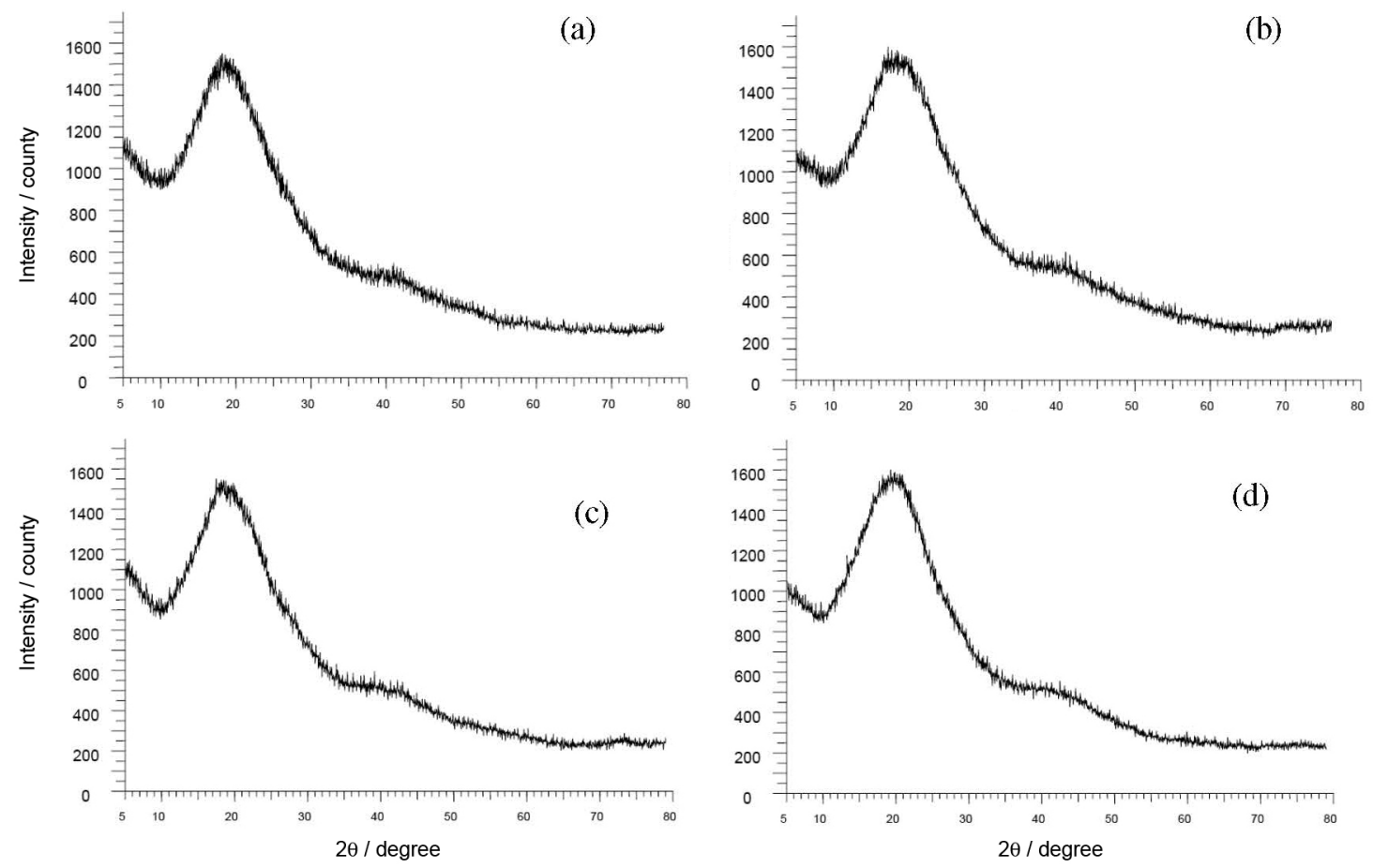

Figure S1. XRD patterns of (a) OMP-TsOH-1, (b) OMP-TsOH-2, (c) OMP-TsOH-4 and (d) OMP-TsOH-5. 

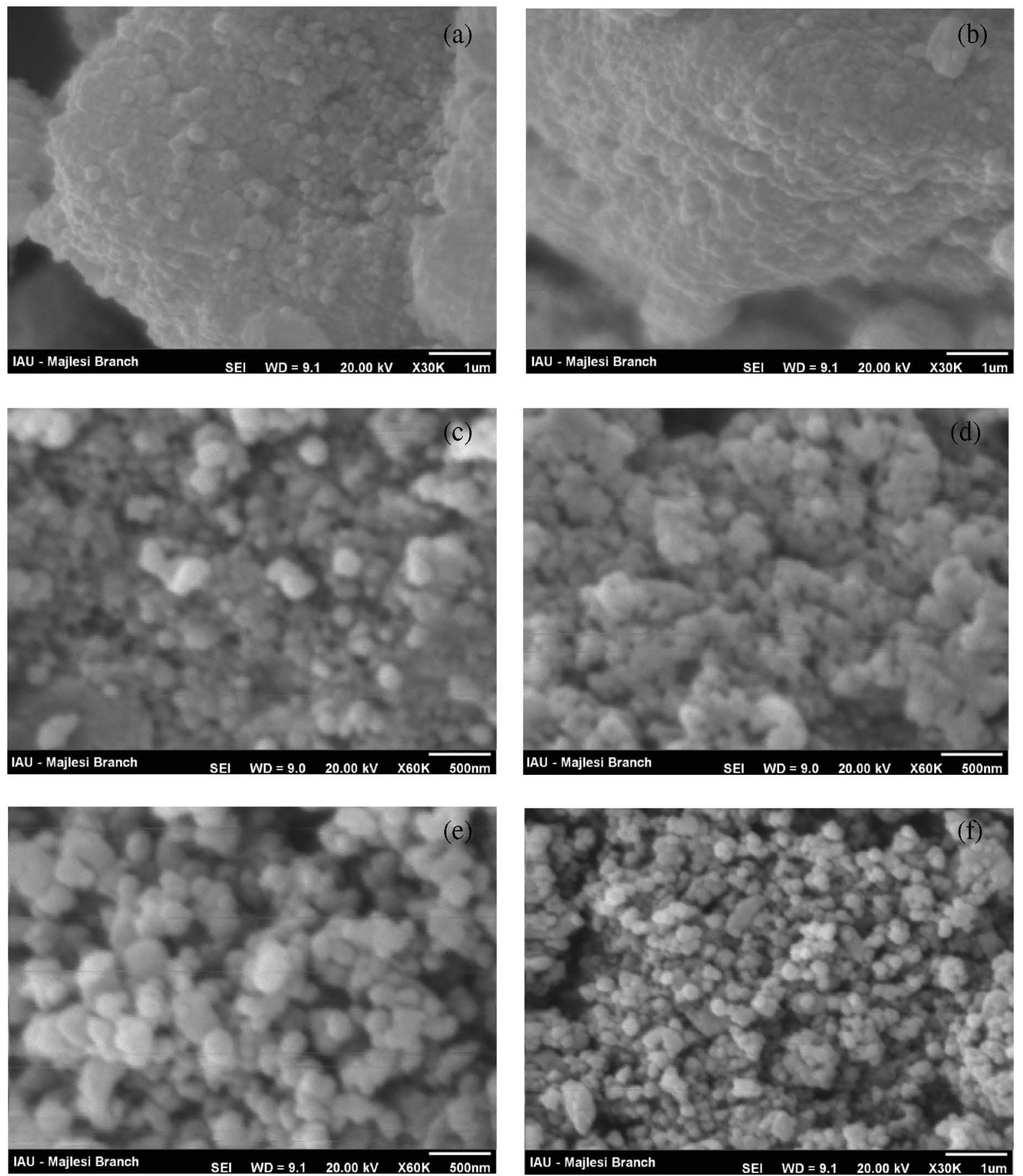

Figure S2. SEM images of (a) OMP-TsOH-1, (b) OMP-TsOH-2, (c) OMP-TsOH-4, (d) OMP-TsOH-5, (e) OMP-TsOH-6 and (f) OMP-TsOH-8. 

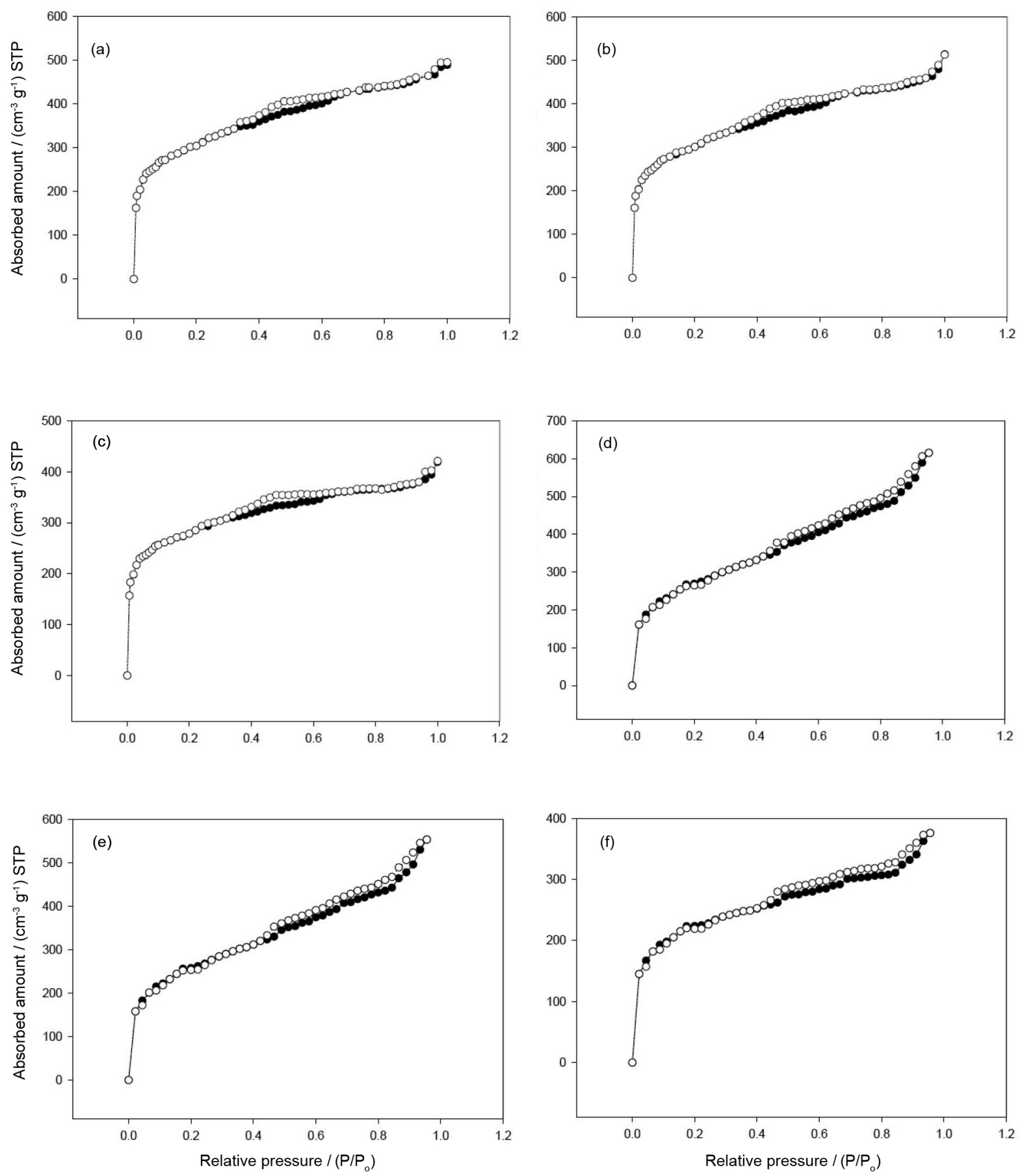

Figure S3. The nitrogen adsorption-desorption isotherms of (a) OMP-TsOH-1, (b) OMP-TsOH-2, (c) OMP-TsOH-4, (d) OMP-TsOH-5, (e) OMP-TsOH-6 and (f) OMP-TsOH-8. 

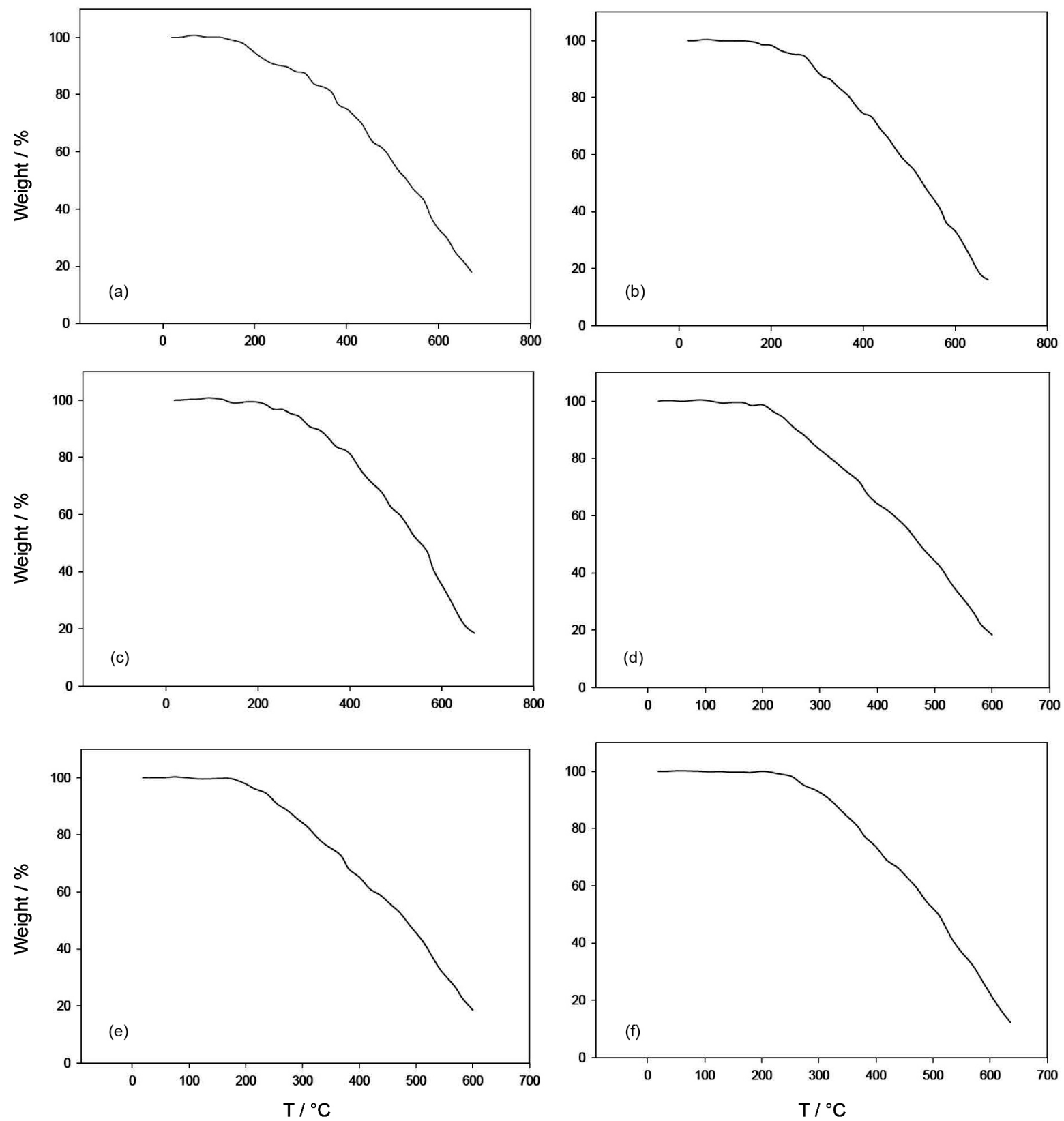

Figure S4. Thermogravimetric curves of (a) OMP-TsOH-1, (b) OMP-TsOH-2, (c) OMP-TsOH-4, (d) OMP-TsOH-5, (e) OMP-TsOH-6 and (f) OMP-TsOH-8.

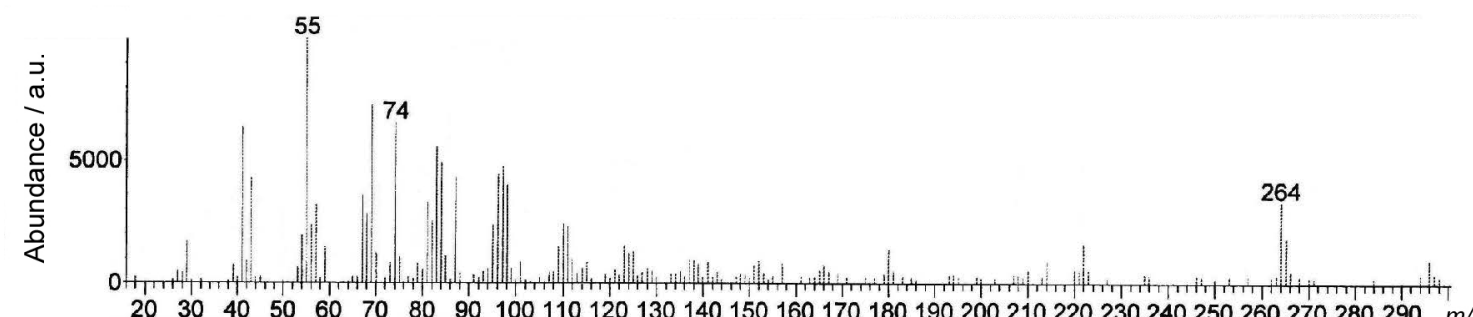

$20304050 \quad 6070 \quad 8090100110120130140150160170180190200210220230240250260270280290 \mathrm{~m} / \mathrm{z}$

Figure S5. Mass spectra of methyl oleate. 